\title{
Sustainable Intensification of Tropical Agro-Ecosystems: Need and Potentials
}

\author{
Christian Andres ${ }^{1,2}$ and Gurbir S. Bhullar ${ }^{1 *}$ \\ ${ }^{1}$ Department of International Cooperation, Research Institute of Organic Agriculture, Frick, Switzerland, ${ }^{2}$ Sustainable \\ Agroecosystems Group, Department of Environmental Systems Science, Institute of Agricultural Sciences, Swiss Federal \\ Institute of Technology, Zurich, Switzerland
}

Rapid population growth, increasingly complex economies and novel industrial uses of agricultural products call for further intensification of agriculture, particularly in the tropics. How to achieve sustainable intensification of food production systems in tropical regions that are challenged by ongoing climate change, loss of natural resources and biodiversity is a matter of debate. Here we highlight the major knowledge gaps in agricultural research and policy that must be addressed to develop adequate governance and regulatory frameworks for sustainable agricultural intensification. They include quantification of the (i) value of (public/private) goods generated by ecosystem services, (ii) costs to conserve the natural resources and biodiversity that maintain ecosystem services, and (iii) true costs of different types of agriculture (in environmental, social, and health dimensions) as well as (iv) required adaptations that will make alternative farming strategies feasible at a global scale. We discuss the synergies and potential of agro-ecology and organic agriculture to transform our food systems and highlight the importance of controlling demand for food through societal (behavioral) and political (structural) changes in agricultural value chains. Finally, we review the sustainability standards and participatory guarantee systems in developed and developing countries, respectively, and argue that exemplars from developed countries could be role models in adapting governance and regulatory frameworks for developing countries.

Keywords: sustainable intensification, tropical agro-ecosystems, organic agriculture, agro-ecology, biodiversity conservation, ecosystem services, Green Revolution, policy frameworks

\section{RATIONALE FOR SUSTAINABLE INTENSIFICATION}

Population growth, urbanization, industrial uses of agricultural products (e.g., biofuels) and the increasing demand for varied diets pose an unprecedented challenge to global agriculture. To tackle these issues, several authors have called for further agricultural intensification (Mueller et al., 2012; Lampkin et al., 2015). How to achieve greater production of food, fiber and fuel in the near future is a matter of debate, as "conventional intensification" implies intensive use of inputs (seeds, fertilizers, and pesticides) to maximize productivity, whereas "ecological intensification" refers to alternative farming systems that respect and conserve natural resources while generating acceptable farm income (SCAR, 2011; Malezieux, 2012; Bommarco et al., 2013). Scholars agree that agricultural intensification needs to be "sustainable," bringing the term "sustainable intensification" on the agenda of agricultural research and policy. However, interpretations of the concept of 
"sustainable intensification" differ substantially, and the discussion often focuses on production, neglecting the consumption end of value chains (Garnett and Godfray, 2012; Loos et al., 2014). In this paper, we adopted Pretty and Bharucha's (2014) definition of sustainable intensification as: " $a$ process or system where agricultural yields are increased without adverse environmental impact and without the conversion of additional non-agricultural land."

Agricultural intensification on a global scale occurred during the Green Revolution that tripled the worldwide cereal harvests between 1950 and 2000, making it possible to provide enough dietary calories for a world population of six billion by the end of the twentieth century (Trewavas, 2002). However, Green Revolution technologies fall within the realm of conventional intensification since they relied heavily on the use of synthetic inputs, and exploited natural resources (Nair, 2014). Although highly productive in the short-term, the large-scale monocultures of the conventional intensification model possess low genetic diversity that renders the crops prone to failure due to natural calamities and epidemics. The negative impacts of conventional agriculture on human health (inadequate use of synthetic pesticides) and the environment (groundwater pollution, high energy consumption for production of inorganic $\mathrm{N}$ fertilizers) is well documented by many authors (Pimentel, 1996; Singh, 2000; Grace et al., 2003; Foley et al., 2005; Chappell and Lavalle, 2011; Bommarco et al., 2013). We argue that such practices are not compatible with sustainable intensification of agriculture, particularly in view of the ongoing climatic changes and diminishing natural resources.

The necessary evil of converting natural ecosystems into farmland probably causes the most severe negative environmental impact of agriculture. In the past century, habitat conversion increased rapidly due to global population growth and the availability of new technologies. Arable land decreased from 0.75 ha per capita in 1900 to 0.35 ha in 1990 and further to 0.2 ha by the beginning of the twenty-first century (Ramankutty et al., 2002). Similarly, arable land is rapidly becoming scarce in developing countries, mainly due to high rates of population growth (Alexandratos, 2005). There is little scope to increase the area under cultivation in the tropics without additional damage to natural ecosystems (except for the reclamation of degraded or deserted lands). Hence sustainable intensification on already established farmlands is of utmost importance; more intensive production on the best agricultural land will allow farmers to get good yields and earn income, which may help avoiding further habitat conversion.

Large-scale monocultures established during the Green Revolution resulted in severe biodiversity loss (Stoate et al., 2001), triggering calls for biodiversity conservation. There are two main arguments to conserve biodiversity: the intrinsic value of nature, and the maintenance of ecosystem functionality/services. Advocates of the first narrative argue that ecosystem functionality/services alone do not sufficiently justify biodiversity conservation (Kleijn et al., 2015). Furthermore, they argue that a number of ecosystem services are non-quantifiable (e.g., water filtration, aesthetic value, etc.; De Groot et al., 2012). The second narrative describes ecosystem functionality/services as private goods of farmers, as functionally important species contribute to yields (e.g., pollination; Balvanera et al., 2001; Isbell et al., 2011; Cardinale et al., 2012). This part of biodiversity is the main focus of ecological intensification (Bommarco et al., 2013). Monetarizing the intrinsic value of nature is complicated, because it represents a public good (e.g., wildlife nutrition; Losey and Vaughan, 2006); estimating the costs to maintain functionally important species is relatively easier, but there are still major research gaps such as the identification of synergies and trade-offs between different ecosystem services. This information is pivotal to harmonize the management of ecosystem services with agriculture, for example through ecological compensation schemes (Lal et al., 2015).

The objective of this article is to highlight the major knowledge gaps in agricultural research and policy regarding sustainable intensification of (tropical) agro-ecosystems and transformation of our food systems. Here we explore the potential of agro-ecology and organic agriculture to lead the transformation at the production end of agricultural value chains, and highlight the need to control food demand through societal (behavioral) and political (structural) changes. Finally, we (i) stress the importance of developing adequate governance and regulatory frameworks, (ii) review some promising sustainability standards/certification schemes, and (iii) argue that exemplars from developed countries could guide respective developments in developing countries.

\section{THE QUEST FOR SUSTAINABLE INTENSIFICATION OF TROPICAL AGRO-ECOSYSTEMS}

By 2050, the tropics will be inhabited by more than half of the world's population (State of the Tropics, 2014). Increases in food demand are going to be greatest in the tropics, and the majority of tropical agro-ecosystems offer substantial scope for intensification. As regions struggling with hunger and poverty are also characterized by low agricultural productivity and rapid population growth, food sufficiency at local levels is pivotal (Tittonell and Giller, 2013). In order to address these challenges, smallholders need agro-ecosystems with which they can simultaneously achieve local food security, cash income and maintenance of natural resource capitals. A multitude of alternative farming strategies (e.g., ecological, eco-, organic or biodynamic agriculture, natural farming, permaculture and agroecology) aim at achieving these objectives (King, 1911; McNeely and Scherr, 2003; Hobbs et al., 2008; Fukuoka and Korn, 2009; Wezel et al., 2009; Paull, 2011).

Many of these strategies are becoming more popular in different parts of the world. They all share the objective to minimize external inputs, enhance system-internal selfregulation and increase the net returns to society. Furthermore, they take into account multiple interactions, synergies and trade-offs between individual parts of the system and build on the efficient use of locally available resources and adapted technologies. Agro-ecology and organic agriculture are among the most prominent alternatives to conventional agriculture. 


\section{Agro-Ecology}

Agro-ecology, claimed by its advocates to be the new agricultural development paradigm (Altieri and Nicholls, 2012), aims at designing innovative agro-ecosystems using a landscape approach, and focuses on social innovations in institutions through dialogs of wisdom (Tittonell, 2013).

Exemplars of sustainable agro-ecosystems include agroforestry systems which support many ecosystem services (Table 1) and could reduce financial risks while, in some cases, having similar returns as coarse-level mixing of trees and crops on separate fields or monocultures (Paul et al., 2015). Other examples are traditional systems which are occasionally managed, e.g., "Dehesas" in Spain or the paddy farms of Thailand; some of these systems are thousands of years old and still exhibit high sustainability (Pimentel et al., 1992; Edwards et al., 1999). Despite producing lower yields of the main crop, such diversified systems are characterized by resilience to climatic extremes (Berg, 2002) and high total productivity, which may minimize risks associated with market fluctuations for farmers (Andres et al., in press). In addition, intercropping systems and various forms of crop rotations increase the abundance of natural pest antagonists, and thereby contribute to pest control (Wyss et al., 2005; Cook et al., 2007; Zehnder et al., 2007; Wyss and Pfiffner, 2008; Forster et al., 2013a; Singh et al., 2015).

While many examples underline the potential of agro-ecology to address food insecurity and biodiversity loss (Chappell and Lavalle, 2011), we question the claim of agro-ecology being "the new agricultural development paradigm" for being somewhat ideological. After all, the complex nature of diversified agroecosystems renders them more labor-intensive compared to mechanized cultivation in monocultures, even after the initially high labor demand is reduced due to self-regulation, and despite the manifold higher resource use efficiencies (energy, water, inputs, etc.). In developed countries, particularly the ones with vast acreage and relatively few people employed in agriculture (e.g., the US), it is increasingly challenging to engage many people for manual labor due to the related costs. Hence we argue that the feasibility of agro-ecology on larger scales in developed countries is yet to be proven. Overcoming this limitation (e.g., through adapted mechanization) remains a challenge for future research. In developing countries, however, the potential of agroecology seems to be relatively greater, because (i) currently there is no shortage of cheap manual labor, (ii) mechanization is largely lacking, and (iii) large acreages that necessarily demand mechanization are rare.

\section{Organic Agriculture}

Organic agriculture is another well-known alternative farming strategy. With organic agriculture becoming ever more popular across the globe (Willer and Lernoud, 2015), certain countries call for its' consolidation (AU, 2011). Although definition and practices of organic agriculture vary significantly from "organic by-default" to "certified organic," the International Federation of Organic Agriculture Movements (IFOAM) serves as an umbrella organization to provide a standardized framework for production and marketing of organic produce (Paull, 2010).
The main critique of organic agriculture is lower productivity; opponents claim that organic agriculture needs more land than conventional agriculture to produce the same amount of food, and thus adoption on large scales may threaten the world's forests, wetlands and grasslands (Trewavas, 2001; Avery, 2006; Pickett, 2013). Depending on the data considered and the methodology applied, studies report the organic-conventional yield gap to range from $-25 \%$ to zero or even higher yields in organic (De Ponti et al., 2012; Seufert et al., 2012; Tuomisto et al., 2012; Ponisio et al., 2015). Since organic systems typically become competitive only after the initial conversion period of 3 years (Panneerselvam et al., 2012), long-term studies showed comparable yields, higher yield stability and higher yields under extreme weather conditions (Lotter et al., 2003; Forster et al., 2013b; Ponisio et al., 2015). At the same time, organic agriculture is significantly more profitable and has higher benefit/cost ratios than conventional agriculture when premium prices are considered (Crowder and Reganold, 2015).

Besides the economic advantage, organic systems exhibit many ecological advantages, e.g., long-term improvement of soil fertility (Reganold et al., 2001; Mader et al., 2002; Hepperly et al., 2006; Fliessbach et al., 2007; Teasdale et al., 2007; Birkhofer et al., 2008). Although it is generally established that organic farms show significantly higher biodiversity, the extent to which this contributes to overall conservation efforts is yet to be quantified (Birkhofer et al., 2014; Tuck et al., 2014). A meta-analysis of European studies by Tuomisto et al. (2012) showed that organic agriculture has positive impacts on the environment per unit area of production, but not necessarily per unit of produce, which again highlights the need to close the organic-conventional yield gap.

The majority of the research comparing organic and conventional agro-ecosystems has been carried out in temperate environments, and the number of similar studies from the tropics is limited. In order to obtain the required evidence, the Research Institute of Organic Agriculture (FiBL) established four long-term field trials in Kenya, India, and Bolivia (Forster et al., 2013b). Initial results suggest a high potential of organic agriculture for ecological intensification of tropical agro-ecosystems (own unpublished data). However, there are major research gaps regarding organic crop production in the tropics, especially regarding pest control and soil fertility maintenance.

\section{Agro-Ecology or Organic Agriculture?}

When comparing the two approaches, we notice that agroecology has a stronger focus on system-internal self-regulation and social institutions, while the main strengths of (certified) organic agriculture are channelized market access and regulatory frameworks. However, similarities among the two approaches abound: (i) promotion of "closed (cyclic) systems," (ii) use of multiple and diverse crops and animals, (iii) capitalizing on biological processes for pest control and soil fertility maintenance, and (iv) support of transition pathways toward ecological intensification of agriculture. Both approaches combine research with practice (Bellon et al., 2009) and strongly 
TABLE 1 | Benefits provided by agroforestry systems reported in the literature.

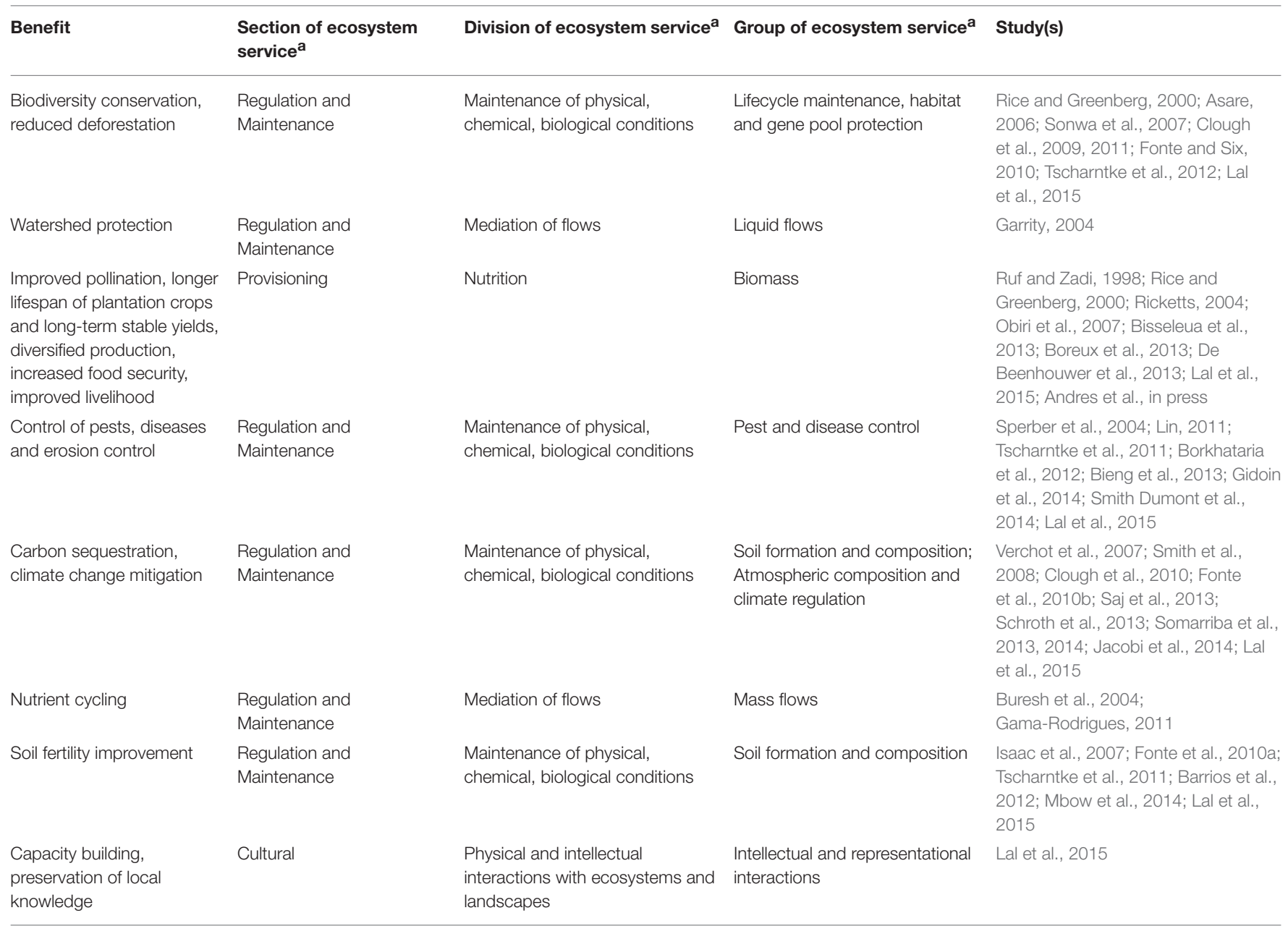

a Section/Division/Group; according to CICES (2016).

advocate societal change, particularly in consumer behavior. Hence we argue that agro-ecology and organic agriculture are complementary, and should be combined to address the challenge of food insecurity in the tropics. By capitalizing on synergies, many issues of agro-ecosystems could be addressed simultaneously, be it at the research-policy interface or on the production and consumption end of value chains.

\section{DRIVERS OF}

\section{TRANSFORMATION-GOVERNANCE AND REGULATORY FRAMEWORKS}

While there is an urgent need to address the research gaps highlighted above, policy action is even more crucial for the required transformation toward higher sustainability of food systems and supply chains. To make progress toward sustainability parameters and indicators outlined in Figure 1, research and policy priorities need to be addressed together, some of which are discussed here.

\section{Consumer Preferences and Cost Internalization}

Urban diets have considerably changed in the past half century, especially in developed countries. Higher consumption of processed foods, edible oils, sugar-sweetened beverages and socalled "empty calories" (energy dense but nutrient poor foods), coupled with the sedentary lifestyle has created the pandemic of obesity which poses a major economic burden to health and social systems (Albritton, 2009; Wang et al., 2011). The "sufficiency" narrative outlined in the third foresight report of the Standing Committee on Agricultural Research (SCAR) of the European Commission emphasizes that, in order to stay within the capacity of system "Earth," increasing food demand needs to be mitigated through behavioral change and structural changes in food systems and supply chains. We need to (i) educate and motivate consumers to opt for healthier and sustainably produced food, (ii) implement governance structures that enhance access to, and affordability of, healthier foods, and (iii) address the disruptive effect of unregulated trade which could 


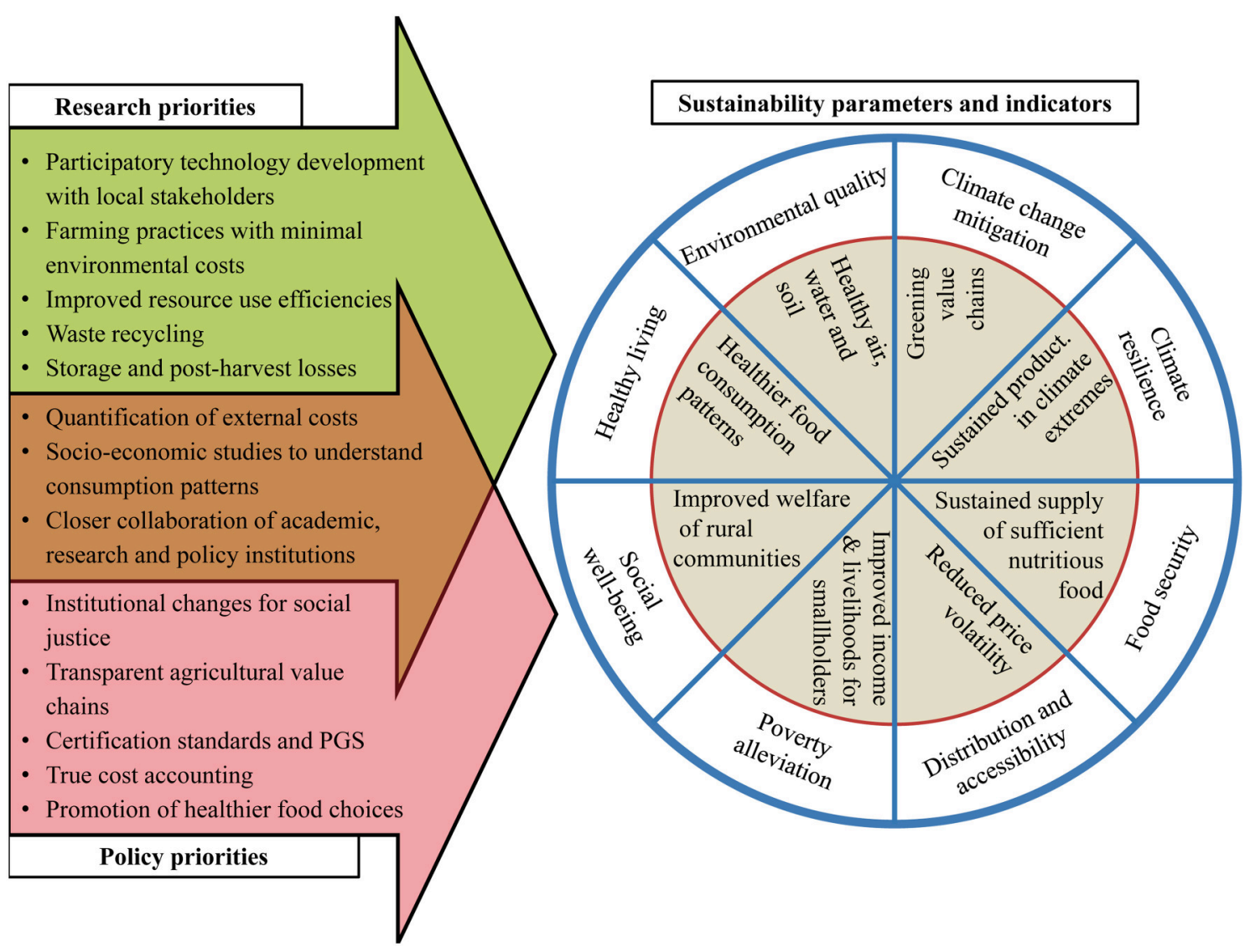

FIGURE 1 | Research and policy priorities for sustainable intensification of agro-ecosystems and supply chains. Inner red circle: sustainability indicators; outer blue circle: sustainability parameters.

facilitate the behavioral change on the consumer side (SCAR, 2011).

In developed countries, we recently witnessed a strong surge in the demand of sustainable/organic produce, surpassing supply (Niggli et al., 2014). While this provides opportunities to market niche products to prosperous consumers, it is certainly insufficient with regard to the mainstreaming of sustainable production at larger scales. We also have to consider that developed countries have, in some cases, been subsidizing sustainable production to an extent that is not feasible for developing countries. Therefore, we argue that developing countries should approach this issue from the consumption side of value chains: as consumer preferences are highly sensitive to price, making conventional produce more expensive by increasing their production costs would increase market demand for sustainable produce. This could serve as a strong positive driver for sustainable intensification of tropical agro-ecosystems.

Current policies and market dynamics favor unsustainable agronomic practices by stimulating the production of single commodities in large quantities, which are sold at distortedly low prices at the cost of the environment and ultimately humankind. Pretty et al. (2000), for instance, reported total external costs of UK agriculture in 1996 to be $208 £$ per ha of arable land/permanent pasture. Another study concluded that the non-monetarized costs of pesticide use in Switzerland amount to at least 50-100 Mio Swiss Francs per year (Zandonella et al., 2014). If these costs would be internalized, conventional produce would become more expensive and sustainable produce more competitive. This may translate into a shift toward higher sustainability of agricultural production (Fry and Finley, 2005; Reisch and Gwozdz, 2010). "True cost accounting" (internalization of external costs) could help to achieve this objective (Pretty et al., 2001; Tegtmeier and Duffy, 2004). However, there are major research gaps in the quantification of the true environmental, social and health costs of different agricultural production systems. Furthermore, the practical implementation of such accounting systems is understandably complex and requires dedicated efforts by policy institutions based on comprehensive research findings.

Farming systems naturally involve trade-offs among competing economic and environmental goals. Therefore, it is important to create the necessary frame conditions that allow the farmer to prioritize both ecosystem services and economic benefits. Switzerland's "multifunctional farmland" approach (adopted after the 1996 referendum) could serve as an exemplar in this regard (Baumgartner, 2000). 


\section{Sustainability Standards and Participatory Guarantee Systems}

Certification standards (e.g., Rainforest Alliance, UTZ Certified, Fairtrade, etc.) integrate sustainable production practices with biodiversity conservation and protection of social rights. In comparison to standards focusing on single aspects, multidimensional standards (e.g., UTZ) target holistic sustainability of agro-ecosystems by balancing economic, social, and environmental criteria. Generally, certification seems to work best when supply/demand ratios in commodity markets are low, and price premiums high. However, as the supply/demand ratios increase, sustainability standards lose their attractiveness because the prices of certified products also decrease. This puts a question mark behind the long-term sustainability of certification standards. In some cases, nationalization of sustainability standards (cf. oil palm sector in Indonesia) may be adequate.

Consumers who are willing to share these responsibilities by paying higher prices for sustainable produce appreciate quality and truthfulness. Despite the tremendous progress sustainability standards have made across various sectors, control mechanisms remain weak in some cases, and there were media reports accusing certification schemes of being prone to fraud (Neuendorff, 2012), or even of cheating producers and consumers (Etahoben et al., 2012). Therefore, assuring integrity and trustworthiness of sustainability standards is of crucial importance, and research and policy should join hands to implement appropriate "checks and balances."

Generally, farmers profited from sustainability standards by gaining access to international markets and receiving training, which improved product quality and helped to conserve natural resources. However, the expected impact on rural livelihoods has been limited, particularly in the case of smallholders (COSA, 2013; Potts et al., 2014). Owing to their stronger bargaining power, processors, traders, retailers and other value chain players fetch relatively larger benefits compared to smallholders (Bjorndal et al., 2014; Meybeck and Redfern, 2014). Moreover, the mandatory conversion periods may discourage conventional farmers to join certification schemes. Therefore, subsidies or incentives for "in-conversion phase" farmers could encourage the adoption of sustainable practices by larger numbers of smallholders. Furthermore, the additional costs for inspection and certification remain a serious hurdle. Often, smallholders can only benefit via group certification, for which they need to form cooperatives. Against this backdrop, the alternative certification scheme "Participatory Guarantee Systems (PGS)" was explored. By putting a focus on smallholders and local consumers, PGS

\section{REFERENCES}

Albritton, R. (2009). Let them eat junk: how capitalism creates hunger and obesity. Pluto Press, p. 272.

Alexandratos, N. (2005). Countries with rapid population growth and resource constraints: issues of food, agriculture, and development. Popul. Dev. Rev. 31, 237. doi: 10.1111/j.1728-4457.2005. 00064.x was successful in different parts of the tropics (Zanasi et al., 2009; Nelson et al., 2010), and local governments are starting to recognize its' role.

Nonetheless, as long as viable governance and regulatory frameworks are not in place yet, case-by-case decisions about appropriate certification systems are needed, especially because their success is context-dependent (farm holdings, cropping systems, target markets and social organization of local populations have to be considered). Countries which were at the forefront of sustainability standards development (e.g., Austria and Switzerland, where 19.5 and $12.2 \%$ of the agricultural land is under certified organic agriculture, respectively (Willer and Lernoud, 2015) could provide role models and assist in the development of appropriate governance and regulatory frameworks in developing countries.

In conclusion, we emphasize that in order to achieve sustainable intensification of (tropical) agro-ecosystems and transform our food systems, the major knowledge gaps outlined in this paper need to be addressed. We need (i) methods to quantify the value of ecosystem services and the costs to maintain them (ii) to know how to adapt alternative farming strategies to ensure their feasibility at global scale, and (iii) to quantify the true costs of different types of agriculture. While this knowledge is crucial to formulate appropriate governance and regulatory frameworks to trigger the developments outlined in this paper, we must not forget that research, education, practice and policy frameworks need to be adapted to local contexts. Finally, we think that advocates of agro-ecology and organic agriculture should join hands to tackle this huge challenge.

\section{AUTHOR CONTRIBUTIONS}

Both CA and GB wrote and revised the article.

\section{ACKNOWLEDGMENTS}

We wish to express our gratitude to Dr. Ulrich Hofmann, Beate Huber, Dr. Amritbir Riar, Gian Nicolay (Research Institute of Organic Agriculture, FiBL) and especially to the reviewers for their very constructive inputs to the contents of this manuscript. Special thanks go to Ursula Bausenwein for the language editing of the manuscript. Our sincere acknowledgement goes to our donors Biovision Foundation for Ecological Development, Coop Sustainability Fund, Liechtenstein Development Service (LED) and the Swiss Agency for Development and Cooperation (SDC) for their continuous financial support and commitment to longterm research. (Dordrecht: Springer Science and Business Media), 1-29.

Andres, C., Comoé, H., Beerli, A., Schneider, M., Rist, S., and Jacobi, J. (in press). "Cocoa in monoculture and dynamic agroforestry," in Sustainable Agriculture Reviews, Vol. 19, ed E. Lichtfouse (Cham: Springer International Publishing).

Asare, R. (2006). "A review on cocoa agroforestry as a means for biodiversity conservation," in Paper Presented at World Cocoa Foundation Partnership 
Conference, Brussels, Belgium, May 2006. Available online at: http:// www.bio.miami.edu/horvitz/bil235/cacao/cacao06/ms/ms\%20Cacao/cocoa \%2520review.pdf (Accessed December 24, 2015).

AU (2011). EX.CL/Dec.600-643(XVIII). AFRICAN UNION, EXECUTIVE COUNCIL, Eighteenth Ordinary Session, 24-28 January 2011, Addis Ababa, Ethiopia, 62. Available online at: http://www.wmo.int/amcomet/sites/default/files/field/doc/events/council_en_ 24_28_january_2011_executive_council_eighteenth_ordinary_session.pdf (Accessed December 24, 2015).

Avery, A. (2006). The Truth About Organic Foods. Chesterfield, MO: Henderson Communications LLC.

Balvanera, P., Daily, G. C., Ehrlich, P. R., Ricketts, T. H., Bailey, S. A., Kark, S., et al. (2001). Conserving biodiversity and ecosystem services. Science 291, 2047-2047. doi: 10.1126/science.291.5511.2047

Barrios, E., Sileshi, G. W., Shepherd, K., and Sinclair, F. (2012). “Agroforestry and soil health: linking trees, soil biota and ecosystem services," in Soil Ecology and Ecosystem Services, eds D. H. Wall, R. D. Bardgett, V. Behan-Pelletier, J. E. Herrick, T. H. Jones, K. Ritz, J. Six, D. R. Strong, and W. H. van der Putten (Oxford, UK: Oxford University Press), 315-330.

Baumgartner, H. (2000). Swiss Agriculture on its Way to Sustainability. Bern: BBL/EDMZ, Schweiz Bundesamt für Umwelt, Wald und Landschaft.

Bellon, S., Lamine, C., Ollivier, G., and De Abreu, L. (2009). The Relationships between Organic Farming and Agroecology. Available online at: http://orgprints. org/22750/1/TheRelationshipsBetweenOrganicFarmingAndAgroecology.pdf (Accessed December 24, 2015).

Berg, H. (2002). Rice monoculture and integrated rice-fish farming in the Mekong Delta, Vietnam - economic and ecological considerations. Ecol. Econ. 41, 95-107. doi: 10.1016/S0921-8009(02)00027-7

Bieng, M. A. N., Gidoin, C., Avelino, J., Cilas, C., Deheuvels, O., and Wery, J. (2013). Diversity and spatial clustering of shade trees affect cacao yield and pathogen pressure in Costa Rican agroforests. Basic Appl. Ecol. 14, 329-336. doi: 10.1016/j.baae.2013.03.003

Birkhofer, K., Bezemer, T. M., Bloem, J., Bonkowski, M., Christensen, S., Dubois, D., et al. (2008). Long-term organic farming fosters below and aboveground biota: implications for soil quality, biological control and productivity. Soil Biol. Biochem. 40, 2297-2308. doi: 10.1016/j.soilbio.2008. 05.007

Birkhofer, K., Ekroos, J., Corlett, E. B., and Smith, H. G. (2014). Winners and losers of organic cereal farming in animal communities across Central and Northern Europe. Biol. Conserv. 175, 25-33. doi: 10.1016/j.biocon.2014. 04.014

Bisseleua, H. B. D., Fotio, D., Yede, Missoup, A. D., and Vidal, S. (2013). Shade tree diversity, Cocoa pest damage, yield compensating inputs and farmers' net returns in West Africa. PLoS ONE 8:e56115. doi: 10.1371/journal.pone.0056115

Bjorndal, T., Child, A., and Lem, A. (2014). Value Chain Dynamics and the Small-Scale Sector: Policy Recommendations for Small-Scale Fisheries and Aquaculture Trade. FAO Fisheries and Aquaculture Technical Paper 581, Rome, Italy, 112. Available online at: http://www.fao.org/fileadmin/user_upload/fisheries/docs/Value_chain_ dynamics_and_the_small-scale_sector.pdf (Accessed December 24, 2015).

Bommarco, R., Kleijn, D., and Potts, S. G. (2013). Ecological intensification: harnessing ecosystem services for food security. Trends Ecol. Evol. 28, 230-238. doi: 10.1016/j.tree.2012.10.012

Boreux, V., Kushalappa, C. G., Vaast, P., and Ghazoul, J. (2013). Interactive effects among ecosystem services and management practices on crop production: pollination in coffee agroforestry systems. Proc. Natl. Acad. Sci. U.S.A. 110, 8387-8392. doi: 10.1073/pnas. 1210590110

Borkhataria, R. R., Collazo, J. A., and Groom, M. J. (2012). Species abundance and potential biological control services in shade vs. sun coffee in Puerto Rico. Agric. Ecosyst. Environ. 151, 1-5. doi: 10.1016/j.agee.2012.01.025

Buresh, R. J., Rowe, E. C., Livesley, S. J., and Cadisch, G. P. M. (2004). "Opportunities for capture of deep soil nutrients," in Below-Ground Interactions in Tropical Agroecosystems: Concepts and Models with Multiple Plant Components, eds M. van Noordwijk, G. Cadisch, and C. K. Ong (Wallingford, UK: CABI Publishing), 109-123.

Cardinale, B. J., Duffy, J. E., Gonzalez, A., Hooper, D. U., Perrings, C., Venail, P., et al. (2012). Biodiversity loss and its impact on humanity. Nature 486, 59-67. doi: $10.1038 /$ nature 11148
Chappell, M. J., and Lavalle, L. A. (2011). Food security and biodiversity: can we have both? An agroecological analysis. Agric. Hum. Values 28, 3-26. doi: 10.1007/s10460-009-9251-4

CICES (2016). CICES Version 4.3. Available online at: http://cices.eu/ (Accessed January 04, 2016).

Clough, Y., Abrahamczyk, S., Adams, M.-O., Anshary, A., Ariyanti, N., Betz, L., et al. (2010). "Biodiversity patterns and trophic interactions in humandominated tropical landscapes in Sulawesi (Indonesia): plants, arthropods and vertebrates," in Tropical Rainforests and Agroforests under Global Change: Ecological and Socio-Economic Valuations, eds T. Tscharntke, C. Leuschner, E. Veldkamp, H. Faust, E. Guhardja, and A. Bidin (Berlin; Heidelberg: SpringerVerlag), 15-71.

Clough, Y., Barkmann, J., Juhrbandt, J., Kessler, M., Wanger, T. C., Anshary, A., et al. (2011). Combining high biodiversity with high yields in tropical agroforests. Proc. Natl. Acad. Sci. U.S.A. 108, 8311-8316. doi: 10.1073/pnas.1016799108

Clough, Y., Putra, D. D., Pitopang, R., and Tscharntke, T. (2009). Local and landscape factors determine functional bird diversity in Indonesian cacao agroforestry. Biol. Conserv. 142, 1032-1041. doi: 10.1016/j.biocon.2008. 12.027

Cook, S. M., Khan, Z. R., and Pickett, J. A. (2007). The use of push-pull strategies in integrated pest management. Annu. Rev. Entomol. 52, 375-400. doi: 10.1146/annurev.ento.52.110405.091407

COSA (2013). The COSA Measuring Sustainability Report: Coffee and Cocoa in 12 Countries. Philadelphia, PA:The Committee on Sustainability Assessment. Available online at: http://thecosa.org/wp-content/uploads/2014/01/TheCOSA-Measuring-Sustainability-Report.pdf (Accessed December 24, 2015).

Crowder, D. W., and Reganold, J. P. (2015). Financial competitiveness of organic agriculture on a global scale. Proc. Natl. Acad. Sci. U.S.A. 112, 7611-7616. doi: $10.1073 /$ pnas. 1423674112

De Beenhouwer, M., Aerts, R., and Honnay, O. (2013). A global meta-analysis of the biodiversity and ecosystem service benefits of coffee and cacao agroforestry. Agric. Ecosyst. Environ. 175, 1-7. doi: 10.1016/j.agee.2013.05.003

De Groot, R., Brander, L., van der Ploeg, S., Costanza, R., Bernard, F., Braat, L., et al. (2012). Global estimates of the value of ecosystems and their services in monetary units. Ecosyst. Serv. 1, 50-61. doi: 10.1016/j.ecoser.2012.07.005

De Ponti, T., Rijk, B., and Van Ittersum, M. K. (2012). The crop yield gap between organic and conventional agriculture. Agric. Syst. 108, 1-9. doi: 10.1016/j.agsy.2011.12.004

Edwards, P. J., Kollmann, J., and Wood, D. (1999). "The agroecosystem in the landscape: implications for biodiversity and ecosystem function," in Agrobiodiversity: Characterization, Utilization and Management, eds D. Wood and J. Lenné (Wallingford, UK: CABI Publishing), 183-210.

Etahoben, B., Dankert, B., Donkerlo, J., Kouassi, S., Tetteh, B., Udonquak, A., et al. (2012). The FAIRTRADE Chocolate Rip-off. Available online at: https://fairreporters.files.wordpress.com/2012/11/the-fairtrade-chocolateripoff-investigation-20122.pdf (Accessed December 24, 2015).

Fliessbach, A., Oberholzer, H.-R., Gunst, L., and Maeder, P. (2007). Soil organic matter and biological soil quality indicators after 21 years of organic and conventional farming. Agric. Ecosyst. Environ. 118, 273-284. doi: 10.1016/j.agee.2006.05.022

Foley, J. A., Defries, R., Asner, G. P., Barford, C., Bonan, G., Carpenter, S. R., et al. (2005). Global consequences of land use. Science 309, 570-574. doi: $10.1126 /$ science. 1111772

Fonte, S. J., Barrios, E., and Six, J. (2010a). Earthworm impacts on soil organic matter and fertilizer dynamics in tropical hillside agroecosystems of Honduras. Pedobiologia 53, 327-335. doi: 10.1016/j.pedobi.2010. 03.002

Fonte, S. J., Barrios, E., and Six, J. (2010b). Earthworms, soil fertility and aggregateassociated soil organic matter dynamics in the Quesungual agroforestry system. Geoderma 155, 320-328. doi: 10.1016/j.geoderma.2009.12.016

Fonte, S. J., and Six, J. (2010). Earthworms and litter management contributions to ecosystem services in a tropical agroforestry system. Ecol. Appl. 20, 1061-1073. doi: 10.1890/09-0795.1

Forster, D., Adamtey, N., Messmer, M. M., Pfiffner, L., Baker, B., Huber, B., et al. (2013a). "Organic agriculture-driving innovations in crop research," in Agricultural Sustainability, eds G. S. Bhullar and N. K. Bhullar (San Diego, CA: Academic Press), 21-46. 
Forster, D., Andres, C., Verma, R., Zundel, C., Messmer, M. M., and Mäder, P. (2013b). Yield and economic performance of organic and conventional cottonbased farming systems - results from a field trial in India. PLoS ONE 8:e81039. doi: 10.1371/journal.pone.0081039

Fry, J., and Finley, W. (2005). The prevalence and costs of obesity in the EU. Proc. Nutr. Soc. 64, 359-362. doi: 10.1079/PNS2005443

Fukuoka, M., and Korn, L. (2009). The One-Straw Revolution: An Introduction to Natural Farming. New York, NY: New York Review Books.

Gama-Rodrigues, A. C. (2011). Soil organic matter, nutrient cycling and biological dinitrogen-fixation in agroforestry systems. Agrofor. Syst. 81, 191-193. doi: 10.1007/s10457-011-9372-9

Garnett, T., and Godfray, H. C. J. (2012). "Sustainable intensification in agriculture. Navigating a course through competing food system priorities," in Food Climate Research Network and the Oxford Martin Programme on the Future of Food (Oxford, UK: University of Oxford), 51.

Garrity, D. P. (2004). Agroforestry and the achievement of the millennium development goals. Agrofor. Syst. 61, 5-17. doi: 10.1007/978-94-0172424-1_1

Gidoin, C., Avelino, J., Deheuvels, O., Cilas, C., and Bieng, M. A. N. (2014). Shade tree spatial structure and pod production explain frosty pod rot intensity in Cacao Agroforests, Costa Rica. Phytopathology 104, 275-281. doi: 10.1094/PHYTO-07-13-0216-R

Grace, P. R., Jainand, M. C., and Harrington, L. W. (2003). "Environmental concerns in Rice-Wheat systems," in Paper Presented at the International Workshop on Development of Action Program for Farm-level Impact in RiceWheat Systems of the Indo-Gangetic Plains (New Delhi), 99-111.

Hepperly, P., Douds, D. Jr., and Seidel, R. (2006). “The Rodale faming systems trial 1981 to 2005: longterm analysis of organic and conventional maize and soybean cropping systems," in Long-Term Field Experiments in Organic Farming, eds J. Raupp, C. Pekrun, M. Oltmanns, and U. Köpke [Bonn, Germany: International Society of Organic Agriculture Resarch (ISOFAR)], 15-32.

Hobbs, P. R., Sayre, K., and Gupta, R. (2008). The role of conservation agriculture in sustainable agriculture. Philos. Trans. R. Soc. Lond. B Biol. Sci. 363, 543-555. doi: $10.1098 /$ rstb.2007.2169

Isaac, M., Ulzen-Appiah, F., Timmer, V., and Quashie-Sam, S. (2007). Early growth and nutritional response to resource competition in cocoa-shade intercropped systems. Plant Soil 298, 243-254. doi: 10.1007/s11104-007-9362-x

Isbell, F., Calcagno, V., Hector, A., Connolly, J., Harpole, W. S., Reich, P. B., et al. (2011). High plant diversity is needed to maintain ecosystem services. Nature 477, 199-203. doi: 10.1038/nature10282

Jacobi, J., Andres, C., Schneider, M., Pillco, M., Calizaya, P., and Rist, S. (2014). Carbon stocks, tree diversity, and the role of organic certification in different cocoa production systems in Alto Beni, Bolivia. Agrofor. Syst. 88, 1117-1132. doi: 10.1007/s10457-013-9643-8

King, F. H. (1911). Farmers of Forty Centuries or Permanent Agriculture in China, Korea and Japan. Available online at: http://www.earthlypursuits.com/FarmFC/FFC/F_\%20H_\%20King\%20Farmers \%20of\%20Forty\%20Centuries.htm (Accessed December24, 2015).

Kleijn, D., Winfree, R., Bartomeus, I., Carvalheiro, L. G., Henry, M., Isaacs, R., et al. (2015). Delivery of crop pollination services is an insufficient argument for wild pollinator conservation. Nat. Commun. 6, 1-8. doi: 10.1038/ ncomms 8414

Lal, R., Singh, B. R., Mwaseba, D. L., Kraybill, D., Hansen, D. O., and Eik, L. O. (2015). Sustainable Intensification to Advance Food Security and Enhance Climate Resilience in Africa. Cham: Springer International Publishing.

Lampkin, N. H., Pearce, B. D., Leake, A. R., Creissen, H., Gerrard, C. L., Girling, R., et al. (2015). "The role of agroecology in sustainable intensification," in Report for the Land Use Policy Group (Newbury: Organic Research Centre, Elm Farm and Game and Wildlife Conservation Trust), 163

Lin, B. B. (2011). Resilience in agriculture through crop diversification: adaptive management for environmental change. Bioscience 61, 183-193. doi: 10.1525/bio.2011.61.3.4

Loos, J., Abson, D. J., Chappell, M. J., Hanspach, J., Mikulcak, F., Tichit, M., et al. (2014). Putting meaning back into "sustainable intensification". Front. Ecol. Environ. 12, 356-361. doi: 10.1890/130157

Losey, J. E., and Vaughan, M. (2006). The economic value of ecological services provided by insects. Bioscience 56, 311-323. doi: 10.1641/00063568(2006)56[311:TEVOES]2.0.CO;2
Lotter, D. W., Seidel, R., and Liebhardt, W. (2003). The performance of organic and conventional cropping systems in an extreme climate year. Am. J. Alternative Agric. 18, 146-154. doi: 10.1079/AJAA200345

Mader, P., Fliessbach, A., Dubois, D., Gunst, L., Fried, P., and Niggli, U. (2002). Soil fertility and biodiversity in organic farming. Science 296, 1694-1697. doi: $10.1126 /$ science. 1071148

Malezieux, E. (2012). Designing cropping systems from nature. Agron. Sustain. Dev. 32, 15-29. doi: 10.1007/s13593-011-0027-z

Mbow, C., Smith, P., Skole, D., Duguma, L., and Bustamante, M. (2014). Achieving mitigation and adaptation to climate change through sustainable agroforestry practices in Africa. Curr. Opin. Environ. Sustain. 6, 8-14. doi: 10.1016/j.cosust.2013.09.002

McNeely, J., and Scherr, S. (2003). Ecoagriculture: Strategies to Feed the World and Save Wild Biodiversity. Washington, DC: Island Press.

Meybeck, A., and Redfern, S. (2014). "Voluntary standards for sustainable food systems: challenges and opportunities," in Paper Presented at a Workshop of the FAO/UNEP Programme on Sustainable Food Systems. FAO headquarters, Rome, Italy, June 2013. Available online at: http://www.fao.org/3/a-i3421e.pdf (Accessed December 24, 2015).

Mueller, N. D., Gerber, J. S., Johnston, M., Ray, D. K., Ramankutty, N., and Foley, J. A. (2012). Closing yield gaps through nutrient and water management. Nature 490, 254-257. doi: 10.1038/nature 11420

Nair, R. P. (2014). Grand challenges in agroecology and land use systems. Front. Environ. Sci. 2:1. doi: 10.3389/fenvs.2014.00001

Nelson, E., Gomez Tovar, L., Schwentesius Rindermann, R., and Gomez Cruz, M. A. (2010). Participatory organic certification in Mexico: an alternative approach to maintaining the integrity of the organic label. Agric. Hum. Values 27, 227-237. doi: 10.1007/s10460-009-9205-x

Neuendorff, J. (2012). "Better safe than sorry - Reasons for international fraud cases - results of the Anti Fraud Initiative," in Presentation at SANA organic fair - Anti Fraud Initiative Workshop, Italy, September 2012. Available online at: http://www.organic-integrity.org/meetings/afi-8-2012/ (Accessed December 24, 2015).

Niggli, U., Baker, B., Rahmann, G., Ssebunya, B., Cuoco, E., Wivstad, M., et al. (2014). A Global Vision and Strategy for Organic Farming Research. Technology Innovation Platform of IFOAM TIPI, First Draft, Frick. Available online at: http://www.organic-research.net/fileadmin/documents_organicresearch/TIPI/ 2014-10-12-GA/TIPI_Vision_First-Draft-October-2014.pdf (Accessed December 24, 2015).

Obiri, B. D., Bright, G. A., McDonald, M. A., Anglaaere, L. C. N., and Cobbina, J. (2007). Financial analysis of shaded cocoa in Ghana. Agrofor. Syst. 71, 139-149. doi: $10.1007 /$ s10457-007-9058-5

Panneerselvam, P., Halberg, N., Vaarst, M., and Hermansen, J. E. (2012). Indian farmers' experience with and perceptions of organic farming. Renew. Agric. Food Syst. 27, 157-169. doi: 10.1017/S1742170511000238

Paul, C., Khasanah, N., Van Noordwijk, M., and Knoke, T. (2015). “Agroforestry, coarse-level mixing of trees and crops or monocultures? land-use decisions under uncertainty," in Resilience of Tropical Ecosystems - Future Challenges and Opportunities, Annual Conference of the Society for Tropical Ecology, eds C. J. Kettle and A. Magrach (Zürich: ETH), 362.

Paull, J. (2010). From France to the world: The International Federation of Organic Agriculture Movements (IFOAM). J. Soc. Res. Policy 1, 93-102.

Paull, J. (2011). Attending the first organic agriculture course: Rudolf Steiner's agriculture course at Koberwitz, 1924. Eur. J. Soc. Sci. 21, 64-70.

Pickett, J. (2013). Food security: intensification of agriculture is essential, for which current tools must be defended and new sustainable technologies invented. Food Energy Secur. 2, 167-173. doi: 10.1002/ fes3.32

Pimentel, D. (1996). Green revolution agriculture and chemical hazards. Sci. Total Environ. 188, S86-S98. doi: 10.1016/0048-9697(96)05280-1

Pimentel, D., Stachow, U., Takacs, D. A., Brubaker, H. W., Dumas, A. R., Meaney, J. J., et al. (1992). Conserving biological diversity in agricultural/forestry systems - most biological diversity exists in human-managed ecosystems. Bioscience 42, 354-362. doi: 10.2307/1311782

Ponisio, L. C., M'Gonigle, L. K., Mace, K. C., Palomino, J., De Valpine, P., and Kremen, C. (2015). Diversification practices reduce organic to conventional yield gap. Proc. R. Soc. B Biol. Sci. 282:20141396. doi: 10.1098/rspb.2014.1396 
Potts, J., Lynch, M., Wilkings, A., Huppé, G., Cunningham, M., and Voora, V. (2014). State of Sustainability Initiatives Review 2014 Standards and the Green Economy. International Institute for Sustainable Development, Winnipeg, Manitoba, Canada and International Institute for Environment and Development, London, UK. Available online at: www.iisd.org/sites/default/files/pdf/2014/ssi_2014.pdf (Accessed December 24, 2015).

Pretty, J., and Bharucha, Z. P. (2014). Sustainable intensification in agricultural systems. Ann. Bot. 114, 1571-1596. doi: 10.1093/aob/mcu205

Pretty, J., Brett, C., Gee, D., Hine, R., Mason, C., Morison, J., et al. (2001). Policy challenges and priorities for internalizing the externalities of modern agriculture. J. Environ. Plann. Manage. 44, 263-283. doi: 10.1080/09640560123782

Pretty, J. N., Brett, C., Gee, D., Hine, R. E., Mason, C. F., Morison, J. I. L., et al. (2000). An assessment of the total external costs of UK agriculture. Agric. Syst. 65, 113-136. doi: 10.1016/S0308-521X(00)00031-7

Ramankutty, N., Foley, J. A., and Olejniczak, N. J. (2002). People on the land: changes in global population and croplands during the 20th Century. AMBIO J. Hum. Environ. 31, 251-257. doi: 10.1579/0044-7447-31.3.251

Reganold, J. P., Glover, J. D., Andrews, P. K., and Hinman, H. R. (2001). Sustainability of three apple production systems. Nature 410, 926-930. doi: $10.1038 / 35073574$

Reisch, L. A., and Gwozdz, W. (2010). Einfluss des Konsumverhaltens auf die Entwicklung von Übergewicht bei Kindern. Bundesgesundheitsblatt Gesundheitsforschung - Gesundheitsschutz 53, 725-732. doi: 10.1007/s00103010-1077-0

Rice, R., and Greenberg, A. (2000). Cacao cultivation and the conservation of biological diversity. AMBIO J. Hum. Environ. 29, 167-173. doi: 10.1579/00447447-29.3.167

Ricketts, T. H. (2004). Tropical forest fragments enhance pollinator activity in nearby coffee crops. Conserv. Biol. 18, 1262-1271. doi: 10.1111/j.15231739.2004.00227.x

Ruf, F., and Zadi, H. (1998). Cocoa: From Deforestation to Reforestation. Paper prepared for the Smithsonian Sustainable Cocoa Congress, Panama. Available online at: http://nationalzoo.si.edu/scbi/migratorybirds/research/ cacao/ruf.cfm (Accessed December 24, 2015).

Saj, S., Jagoret, P., and Ngogue, H. T. (2013). Carbon storage and density dynamics of associated trees in three contrasting Theobroma cacao agroforests of Central Cameroon. Agrofor. Syst. 87, 1309-1320. doi: 10.1007/s10457-0139639-4

SCAR (2011). "Sustainable food consumption and production in a resourceconstrained world," in European Commission - Standing Committee on Agricultural Research (SCAR), The 3rd SCAR Foresight Exercise (Brussels), 150.

Schroth, G., Bede, L., Paiva, A., Cassano, C., Amorim, A., Faria, D., et al. (2013). Contribution of agroforests to landscape carbon storage. Mitigation Adapt. Strateg. Glob. Change 20, 1175-1190. doi: 10.1007/s11027-013-9530-7

Seufert, V., Ramankutty, N., and Foley, J. A. (2012). Comparing the yields of organic and conventional agriculture. Nature 485, 229. doi: $10.1038 /$ nature 11069

Singh, A., Zytynska, S., Hanna, R., and Weisser, W. (2015). "Maximize production, minimize space: potential benefits of intercropping at high densities for okra farmers in cameroon," in Resilience of Tropical Ecosystems - Future Challenges and Opportunities, Annual Conference of the Society for Tropical Ecology, eds C. J. Kettle and A. Magrach (Zürich: ETH), 362.

Singh, R. B. (2000). Environmental consequences of agricultural development: a case study from the Green Revolution state of Haryana, India. Agric. Ecosyst. Environ. 82, 97-103. doi: 10.1016/S0167-8809(00)00219-X

Smith, P., Martino, D., Cai, Z., Gwary, D., Janzen, H., Kumar, P., et al. (2008). Greenhouse gas mitigation in agriculture. Philos. Trans. R. Soc. Lond. B Biol. Sci. 363, 789-813. doi: 10.1098/rstb.2007.2184

Smith Dumont, E., Gnahoua, G. M., Ohouo, L., Sinclair, F. L., and Vaast, P. (2014). Farmers in Côte d'Ivoire value integrating tree diversity in cocoa for the provision of ecosystem services. Agrofor. Syst. 88, 1047-1066. doi: 10.1007/s10457-014-9679-4

Somarriba, E., Cerda, R., Orozco, L., Cifuentes, M., Davila, H., Espin, T., et al. (2013). Carbon stocks and cocoa yields in agroforestry systems of Central America. Agric. Ecosyst. Environ. 173, 46-57. doi: 10.1016/j.agee.2013. 04.013
Somarriba, E., Suárez-Islas, A., Calero-Borge, W., Villota, A., Castillo, C., Vílchez, S., et al. (2014). Cocoa-timber agroforestry systems: Theobroma cacao-Cordia alliodora in Central America. Agrofor. Syst. 88, 1001-1019. doi: 10.1007/s10457014-9692-7

Sonwa, D. J., Nkongmeneck, B. A., Weise, S. F., Tchatat, M., Adesina, A. A., and Janssens, M. J. J. (2007). Diversity of plants in cocoa agroforests in the humid forest zone of Southern Cameroon. Biodivers. Conserv. 16, 2385-2400. doi: 10.1007/s10531-007-9187-1

Sperber, C. F., Nakayama, K., Valverde, M. J., and Neves, F. D. (2004). Tree species richness and density affect parasitoid diversity in cacao agroforestry. Basic Appl. Ecol. 5, 241-251. doi: 10.1016/j.baae.2004.04.001

State of the Tropics (2014). State of the Tropics 2014 Report. Cairns, QLD: James Cook University.

Stoate, C., Boatman, N. D., Borralho, R. J., Carvalho, C. R., De Snoo, G. R., and Eden, P. (2001). Ecological impacts of arable intensification in Europe. J. Environ. Manage. 63, 337-365. doi: 10.1006/jema.2001.0473

Teasdale, J. R., Coffman, C. B., and Mangum, R. W. (2007). Potential long-term benefits of no-tillage and organic cropping systems for grain production and soil improvement. Agron. J. 99, 1297-1305. doi: 10.2134/agronj2006.0362

Tegtmeier, E. M., and Duffy, M. D. (2004). External costs of agricultural production in the United States. Int. J. Agric. Sustain. 2, 1-20. doi: 10.1080/14735903.2004.9684563

Tittonell, P. (2013). Farming Systems Ecology - Towards Ecological Intensification of World Agriculture. Available online at: https://www.wageningenur.nl/upload_mm/8/3/e/8b4f46f7-4656-4f68-bb11905534c6946c_Inaugural\%20lecture\%20Pablo\%20Tittonell.pdf (Accessed December 24, 2015)

Tittonell, P., and Giller, K. E. (2013). When yield gaps are poverty traps: the paradigm of ecological intensification in African smallholder agriculture. Field Crops Res. 143, 76-90. doi: 10.1016/j.fcr.2012.10.007

Trewavas, A. (2001). Urban myths of organic farming. Nature 410, 409-410. doi: $10.1038 / 35068639$

Trewavas, A. (2002). Malthus foiled again and again. Nature 418, 668-670. doi: 10.1038/nature 01013

Tscharntke, T., Clough, Y., Bhagwat, S. A., Buchori, D., Faust, H., Hertel, D., et al. (2011). Multifunctional shade-tree management in tropical agroforestry landscapes - a review. J. Appl. Ecol. 48, 619-629. doi: 10.1111/j.13652664.2010.01939.x

Tscharntke, T., Clough, Y., Wanger, T. C., Jackson, L., Motzke, I., Perfecto, I., et al. (2012). Global food security, biodiversity conservation and the future of agricultural intensification. Biol. Conserv. 151, 53-59. doi: 10.1016/j.biocon.2012.01.068

Tuck, S. L., Winqvist, C., Mota, F., Ahnstrom, J., Turnbull, L. A., and Bengtsson, J. (2014). Land-use intensity and the effects of organic farming on biodiversity: a hierarchical meta-analysis. J. Appl. Ecol. 51, 746-755. doi: 10.1111/13652664.12219

Tuomisto, H. L., Hodge, I. D., Riordan, P., and Macdonald, D. W. (2012). Does organic farming reduce environmental impacts? - A meta-analysis of European research. J. Environ. Manage. 112, 309-320. doi: 10.1016/j.jenvman.2012.08.018

Verchot, L. V., Noordwijk, M. V., Kandji, S., Tomich, T., Ong, C., Albrecht, A., et al. (2007). Climate change: linking adaptation and mitigation through agroforestry. Mitigation Adapt. Strateg. Glob. Change 12, 901-918. doi: 10.1007/s11027-007-9105-6

Wang, Y. C., McPherson, K., Marsh, T., Gortmaker, S. L., and Brown, M. (2011). Health and economic burden of the projected obesity trends in the USA and the UK. Lancet 378, 815-825. doi: 10.1016/S0140-6736(11)60814-3

Wezel, A., Bellon, S., Doré, T., Francis, C., Vallod, D., and David, C. (2009). Agroecology as a science, a movement and a practice. A review. Agron. Sustain. Dev. 29, 503-515. doi: 10.1051/agro/2009004

Willer, H., and Lernoud, J. (eds.). (2015). The World of Organic Agriculture Statistics and Emerging Trends 2015. FiBL-IFOAM Report, Research Institute of Organic Agriculture (FiBL), Frick, and IFOAM Organic International, Bonn

Wyss, E., Luka, H., Pfiffner, L., Schlatter, C., Uehlinger, G., and Daniel, C. (2005). "Approaches to pest management in organic agriculture: a case study in European apple orchards," in Paper Presented at Symposium "IPM in Organic Systems", XXII International Congress of Entomology (Brisbane, QLD). Available online at: https://www.researchgate.net/publication/262002057_Approaches_to_ 
management_in_organic_agriculture_a_case_study_in_European_apple_ orchards (Accessed December 24, 2015).

Wyss, E., and Pfiffner, L. (2008). Biodiversity in organic horticulture - an indicator for Sustainability and a tool for pest management. Acta Hortic. 767, 75-80. doi: 10.17660/ActaHortic.2008.767.6

Zanasi, C., Venturi, P., Setti, M., and Rota, C. (2009). Participative organic certification, trust and local rural communities development: the Case of Rede Ecovida. New Medit. 2, 56-64.

Zandonella, R., Sutter, D., Liechti, R., and Von Stokar, T. (2014). Volkswirtschaftliche Kosten des Pestizideinsatzes in der Schweiz - Pilotberechnung. Available online at: http://www.pronatura.ch/landwirtschaft?file=tl_files/dokumente_de/2_unsere _themen/landwirtschaft/pestizide/Studie\%20Volkswirtschaftliche\%20Kosten\% 20Pestizideinsatzes\%20Schweiz.pdf (Accessed December 24, 2015).
Zehnder, G., Gurr, G. M., Kuehne, S., Wade, M. R., Wratten, S. D., and Wyss, E. (2007). Arthropod pest management in organic crops. Annu. Rev. Entomol. 52, 57-80. doi: 10.1146/annurev.ento.52.110405.091337

Conflict of Interest Statement: The authors declare that the research was conducted in the absence of any commercial or financial relationships that could be construed as a potential conflict of interest.

Copyright (c) 2016 Andres and Bhullar. This is an open-access article distributed under the terms of the Creative Commons Attribution License (CC BY). The use, distribution or reproduction in other forums is permitted, provided the original author(s) or licensor are credited and that the original publication in this journal is cited, in accordance with accepted academic practice. No use, distribution or reproduction is permitted which does not comply with these terms. 